\title{
Targum Neofiti 1 - Księga Wyjścia. Tekst aramejski - przekład, aparat krytyczny - przypisy, przekład i opracowanie Mirosław S. Wróbel, Wydawnictwo Archidiecezji Lubelskiej Gaudium, Lublin 2017, 471 s. (Biblia Aramejska, 2)
}

Sylwester Jędrzejewski SDB

Uniwersytet Papieski Jana Pawła II w Krakowie

sylwester.jedrzejewski@upjp2.edu.pl (D) https://orcid.org/0000-0002-0619-1106

Z inicjatywy ks. prof. dra hab. Mirosława Wróbla, kierownika Katedry Filologii Biblijnej i Literatury Międzytestamentalnej Wydziału Teologii Katolickiego Uniwersytetu Lubelskiego Jana Pawła II, ukazał się drugi tom polskiego przekładu targumów, czyli Biblii Aramejskiej. Pierwszym tomem dzieła był tekst aramejski Targumu Neofiti 1 do Księgi Rodzaju, jego przekład wraz z aparatem krytycznym i ułatwiające lekturę przypisy. Tom drugi zbudowany jest analogicznie. Tłumaczenie zostało dokonane z wydania krytycznego zredagowanego przez Alejandra Díeza Macha: Neophyti. I Targum Palestinense. MS de la Biblioteca Vaticana, t. 2: Éxodo, Madrit-Barcelona 1970. Poprzedza je słowo napisane przez prof. Jamesa H. Charleswortha. Autor przekładu i równocześnie redaktor edycji Biblii Aramejskiej oraz grono współpracowników przekazują czytelnikowi dzieło wielkie i ważne.

Targumy, czyli aramejskie tłumaczenia biblijnych tekstów hebrajskich, najpierw ustne, a potem spisane, cechują się charakterem wyjaśniającym, interpretującym i często parafrazującym. Są swoistą refleksją środowiskową zwieńczoną wyjaśnieniami zawiłości, niejasności lub niekonsekwencji tekstu hebrajskiego. Wreszcie są także reinterpretacją i aktualizującą aplikacją, starającą się wyjaśnić stawiane wówczas przez Żydów problemy i odpowiedzieć na pytania.

Głównym motywem ich powstawania, przy niewielkiej znajomości języka hebrajskiego w późnym okresie Drugiej Świątyni, było udostępnienie świętych tekstów w powszechnie używanym przez Żydów języku. Własne targumy tworzyło wiele grup judaistycznych późnego okresu Drugiej Świątyni, stąd mnogość i jednocześnie ich zróżnicowanie, z tendencją do pewnej idealizacji, zwłaszcza prawa. Tendencja ta być może rodziła kwestie dyskusyjne, jako 
że przechodząc od etapu żywego wydarzenia ustnego, targumy zaczęły być utrwalane $\mathrm{w}$ formie literackiej, a ich oddziaływanie poszerzało się. Stąd opinia rabiniczna, aczkolwiek bez cech powszechności, o ograniczeniu ich do lektury prywatnej.

W zjawisku targumizmu można mówić o swoistej „transplantacji”, w której targeman nierzadko odchodził od wierności tekstowi biblijnemu na rzecz przekazania jego sensu, uwzględniającego - nawet bez specjalnych intencji aktualne uwarunkowania wspólnot żydowskich. Ponadto tworzący się targum musiał uwzględnić istotę liturgii synagogalnej, pozbawionej z oczywistych powodów elementów ofiarniczych, włączając ją w żywy nurt codzienności. Słowo Boga wchodziło w ten sposób w interakcję z żydowskim życiem wyrażanym w synagogalnej liturgii.

Targumy szukały zrozumiałego przekładu, czyniły glossy wyjaśniające, reflektowały idee swego czasu i środowiska, a wprowadzając parafrazy moralne i zachęty, wpływały na życie codzienne. Tworzyły także nową targumiczną teologię. Targumizm był naturalnym środowiskiem Jezusa, jego pierwszych uczniów i pierwotnej wspólnoty Kościoła. Stąd cieszy kolejna publikacja Biblii Aramejskiej.

Jej studium pozwoli teologom, osobom zainteresowanym głębszym poznaniem tekstów biblijnych i ich orędzia na pogłębienie swoich kompetencji, a także zaspokojenie naturalnej naukowej ciekawości. Otrzymujemy też kolejne narzędzie dla biblijnych studiów porównawczych. Ponadto wydanie to należy - jak pisze jego redaktor - wskazać jako ważne źródło w konstruowaniu dialogu chrześcijańsko-żydowskiego. Aparat krytyczny, objaśnienia zawarte w przypisach, przybliżenie specyficznych dla targumu zwrotów, a zwłaszcza eksplikacja targumicznych poszerzeń to niezwykle wartościowe elementy dzieła.

Wprowadzając do edycji Księgi Wyjścia z Targumu Neofiti 1, prof. Charlesworth pisze: „Jeśli chcemy udoskonalić nasze rozumienie Pisma, to powinniśmy poznać sposób, w jaki starożytni Żydzi pojmowali Słowo Boga. Targumy to jedno z głównych źródeł, z jakich możemy czerpać” (s. XXII). 